\title{
The effects of restricting enzyme supplementation in rye-based diets for broilers
}

\author{
C.I. Santos ${ }^{a}$, T. Ribeiro ${ }^{b}$, P.I.P. Ponte ${ }^{b, c}$, V.O. Fernandes ${ }^{\text {b,c }}$, L. Falcão ${ }^{a}$, \\ J.P. Freire ${ }^{a}$, J.A.M. Prates ${ }^{b}$, L.M.A. Ferreira ${ }^{b}$, C.M.G.A. Fontes ${ }^{\text {b, }}{ }^{\text {, M.M. Mordelo }}{ }^{a}$ \\ a Instituto Superior de Agronomia, Tapada da Ajuda, 1349-017 Lisboa, Portugal \\ b CIISA - Faculdade de Medicina Veterinária, Pólo Universitário do Alto da Ajuda, Avenida da Universidade Técnica, 1300-477 Lisboa, \\ Portugal \\ c NZYTech Ltd., Campus do Lumiar, Estrada do Paço do Lumiar, 1649-038 Lisboa, Portugal
}

\section{A R T I C L E I N F O}

\section{Article history:}

Received 6 February 2013

Received in revised form 17 October 2013

Accepted 18 October 2013

\section{Keywords:}

Broiler

Enzyme

Rye

Xylanase

\begin{abstract}
A B S T R A C T
The purpose of the current study was to restrict enzyme addition in order to evaluate if supplementation throughout the broiler production cycle is required. Here we analyze the possibility of circumscribing xylanase supplementation in rye-based diets to the earliest periods of the life of the broiler. In the current experiment, 1-day-old chicks were divided into 5 treatments and fed a rye-based diet supplemented with a commercial enzyme mixture containing a microbial xylanase. The five treatments consisted of birds fed a nonsupplemented diet and birds fed diets supplemented with the exogenous enzyme for the entire period of the experiment ( 28 days), the first 21 days, the first 14 days or the first 7 days of the trial. The data revealed that broilers fed diets supplemented with enzymes during 28 days had similar $(P>0.05)$ growth performance, gastrointestinal enzyme activity and relative organ sizes to broilers fed supplemented diets only in the first 21 days of the experimental period. These results suggest that the action of exogenous enzymes, when used to supplement rye-based diets for broilers, may be restricted to the first 21 days of the broiler's production cycle without compromising animal performance.
\end{abstract}

(C) 2013 Elsevier B.V. All rights reserved.

\section{Introduction}

The use of rye in broiler diets may be limited due to the presence of soluble non-starch polysaccharides (NSP), particularly arabinoxylans, which create a viscous environment within the intestinal lumen (Smits and Annison, 1996; Józefiak et al., 2007). Increased viscosity impairs digestibility and absorption of dietary nutrients leading to a depression in growth rate and feed conversion ratio (FCR) (Antoniou and Marquardt, 1981; Bedford, 1993). Some commercial xylanases are able to reduce the degree of polymerization of the soluble anti-nutritive and recalcitrant carbohydrates that are abundant in cereal-based diets. Thus, enzyme supplementation in diets containing significant levels of soluble NSP leads to a reduction in digesta viscosity, resulting in more efficient nutrient digestion and absorption (Smits and Annison, 1996; Silva and Smithard, 2002; Józefiak et al., 2007). As a consequence, there is an improvement in broiler performance (Dusel et al., 1998; Bedford, 2000).

Ingredients such as barley and especially rye contain high levels of soluble carbohydrates that can hold water in the digesta producing a thick viscous solution and very wet excreta (Choct and Annison, 1990; Knudsen, 1997; Silva and

\footnotetext{
Abbreviations: BW, body weight; FCR, feed conversion ratio; GI, gastrointestinal; NSP, non-starch polysaccharide.

* Corresponding author at: Faculdade de Medicina Veterinária, Universidade Técnica de Lisboa, Avenida da Universidade Técnica, 1300-477 Lisboa, Portugal. Tel.: +351 213652876; fax: +351 213652889.

E-mail addresses: cafontes@fmv.utl.pt (C.M.G.A. Fontes), mlordelo@isa.utl.pt (M.M. Lordelo).
} 
Table 1

Composition and calculated analysis of the rye-based diet. ${ }^{a}$

\begin{tabular}{lc}
\hline Ingredient & $\mathrm{g} / \mathrm{kg}$ of diet \\
\hline Rye & 580 \\
Soybean meal, $470 \mathrm{~g} / \mathrm{kg} \mathrm{CP}$ & 320 \\
Soybean oil & 40.0 \\
Sodium chloride & 3.0 \\
Calcium carbonate & 22.4 \\
Dicalcium phosphate & 10.6 \\
DL-Methionine & 2.0 \\
Mineral and vitamin premix & 2.0 \\
Filler & 20.0 \\
Calculated nutrient content & \\
Metabolizable energy $(\mathrm{MJ} / \mathrm{kg})$ & 11.7 \\
Crude protein & 226 \\
Lysine & 11.2 \\
Methionine & 4.9 \\
Calcium & 9.1 \\
Available phosphorus & 4.0 \\
\hline
\end{tabular}

a Treatments consisted of a rye-based diet supplemented with enzyme for the entire 28 days, the first 21 days, the first 14 days, the first 7 days or not supplemented.

b Mineral-vitamin premix provided the following per kilogram of diet: biotin $0.5 \mathrm{mg}$, calcium pantothenate $10 \mathrm{mg}$, cholecalciferol $0.05 \mathrm{mg}$, cyanocobalamin $0.12 \mathrm{mg}$, folic acid $0.5 \mathrm{mg}$, menadione $2 \mathrm{mg}$, nicotinic acid $30 \mathrm{mg}$, pyridoxine $1.7 \mathrm{mg}$, retinol $2.7 \mathrm{mg}$, thiamin $1 \mathrm{mg}$, $\alpha$-tocopherol $20 \mathrm{mg}$, riboflavin, $4.2 \mathrm{mg}$, Co $0.2 \mathrm{mg}$, Cu $10 \mathrm{mg}$, Fe $80 \mathrm{mg}$, I $1 \mathrm{mg}$, Mn $100 \mathrm{mg}$, Se $0.3 \mathrm{mg}$, Zn $80 \mathrm{mg}$.

c The filler consisted of ground rye. When enzyme supplementation was provided, the filler was used to mix the enzyme onto the diet. When no enzyme supplementation was provided, the filler was added alone.

d Calculation of nutrient content based on Ingredient Analysis Table (Feedstuffs, 2009).

Smithard, 2002). It has been documented that broilers fed barley-based diets display an improved performance in response to $\beta$-glucanase supplementation, in particular at the early stages of their life (Newman and Newman, 1988; Rotter et al., 1989; Nahas and Lefrançois, 2001). However, information on age-related efficacy of xylanase supplementation to ryebased diets is scarce. Mourão and Pinheiro (2009) have found that the reduction of body weight (BW) and increase in FCR with diets based on rye in comparison to diets based on corn was attenuated with age. Therefore, these authors (Mourão and Pinheiro, 2009) found, in a 35 day trial, that xylanase supplementation to a rye-based diet had significant effects on FCR only until 21 days of age. Here, we hypothesize that broilers fed on rye-based diets should be more responsive to exogenous enzymes at the initial weeks of growth. In this study, the capacity of xylanases to affect the performance of broilers fed rye-based diets was explored by circumscribing enzyme supplementation to different phases up to 28 days of age.

\section{Materials and methods}

One hundred and sixty 1-day-old Ross 308 male broiler chicks birds were assigned to 40 cages of 4 birds each with each cage measuring $48 \mathrm{~cm} \times 55 \mathrm{~cm}$. Chicks were wing-banded for individual identification. The 40 cages were randomly assigned to 5 treatments consisting of a rye-based diet supplemented with the commercial enzyme mixture Avizyme 1100 containing a minimum of $2500 \mathrm{U} / \mathrm{g}$ of endo-1,4- $\beta$-xylanase, and $800 \mathrm{U} / \mathrm{g}$ of protease (Danisco Animal Nutrition DuPont Industrial Biosciences, Marlborough, UK) at a $0.05 \%(\mathrm{w} / \mathrm{w})$ inclusion rate for the entire 28 days (treatment R1-28), the first 21 days (treatment R1-21), the first 14 days (treatment R1-14) or the first 7 days (treatment R1-7) of the trial, the fifth group was fed a non-supplemented basal diet (treatment R0). The basal diet (Table 1) contained $60 \%$ of rye and was formulated to meet the nutrient requirements defined by the NRC (1994). Chicks were given free access to water and pelleted feed that was then crumbled. Feed consumption and BW was determined weekly throughout the experiment, and mortality was recorded daily. At 28 days of age, one bird per pen was slaughtered by an intravenous injection of an aqueous isotonic solution of $125 \mathrm{mg}$ Thiopental (Braun, Barcelona, Spain). The gastrointestinal (GI) organs were removed and emptied with running water. The weight of the crop, gizzard and liver, and the length of the duodenum, jejunum, ileum and caecum were measured. Digesta samples were collected at the various GI compartments to measure contents viscosity. To measure the viscosity of small intestine contents, samples were collected from the duodenum plus jejunum and ileum, centrifuged for 10 min at $10,867 \times g$ and the viscosity of sample supernatant was measured at $6 \mathrm{rpm}$ using a viscometer (Model LVDVCP-II, Brookfield Engineering Laboratories, Middleboro, MA) with a cup maintained at $24^{\circ} \mathrm{C}$. Due to the high viscosity of digesta samples from birds consuming a rye-based diet, $500 \mu \mathrm{l}$ of sample was diluted with $500 \mu \mathrm{l}$ of water before viscosity measurements were taken.

Data related to bird performance were subjected to ANOVA according to the general linear models procedure of SAS SAS Institute (2001). The Tukey's procedure was used to detect significant differences between treatment groups. In addition, polynomial contrasts were used to evaluate differences between periods of feed supplementation. Differences were considered significant when $\mathrm{P}<0.05$. 
Table 2

Body weight, feed intake and feed conversion rate of broilers fed a rye-based diet supplemented with enzyme in specific periods.

\begin{tabular}{|c|c|c|c|c|c|c|c|c|c|c|}
\hline & \multicolumn{5}{|c|}{ Treatment $^{\mathrm{a}}$} & \multicolumn{5}{|c|}{ Contrasts } \\
\hline & Ro & $\mathrm{R} 1-7$ & $\mathrm{R} 1-14$ & $\mathrm{R} 1-21$ & $\mathrm{R} 1-28$ & SEM & $\mathrm{R} 0$ vs R1-28 & $\mathrm{R} 1-7$ vs R1-28 & $\mathrm{R} 1-14$ vs $\mathrm{R} 1-28$ & $\mathrm{R} 1-21$ vs $\mathrm{R} 1-28$ \\
\hline \multicolumn{11}{|c|}{ Body weight (g) } \\
\hline $7 d$ & $134^{y}$ & $141^{x y}$ & $144^{x y}$ & $147^{x}$ & $145^{x y}$ & 1.264 & 0.007 & 0.243 & 0.773 & 0.550 \\
\hline $14 d$ & $334^{y}$ & $351^{x y}$ & $366^{x}$ & $365^{x}$ & $374^{x}$ & 3.335 & $<0.001$ & 0.026 & 0.424 & 0.371 \\
\hline $21 d$ & 652 & 665 & 686 & 705 & 701 & 6.383 & 0.016 & 0.074 & 0.456 & 0.856 \\
\hline $28 d$ & $919^{z}$ & $946^{\mathrm{yz}}$ & $979^{x y z}$ & $1002^{x y}$ & $1033^{x}$ & 9.792 & $<0.001$ & 0.005 & 0.075 & 0.300 \\
\hline \multicolumn{11}{|c|}{ Feed intake (g) } \\
\hline $0-7 d$ & 127 & 139 & 133 & 143 & 137 & 2.167 & 0.137 & 0.789 & 0.475 & 0.391 \\
\hline $7-14 d$ & 352 & 357 & 354 & 357 & 358 & 2.424 & 0.436 & 0.876 & 0.619 & 0.894 \\
\hline $14-21 d$ & 587 & 581 & 580 & 590 & 585 & 3.456 & 0.861 & 0.745 & 0.692 & 0.651 \\
\hline $21-28 d$ & $776^{x y}$ & $770^{x y}$ & $729^{y}$ & $811^{x}$ & $799^{x y}$ & 9.213 & 0.414 & 0.302 & 0.014 & 0.646 \\
\hline $0-28 d$ & 1842 & 1848 & 1796 & 1901 & 1879 & 13.689 & 0.385 & 0.456 & 0.054 & 0.594 \\
\hline \multicolumn{11}{|c|}{ Feed conversion rate $(\mathrm{g} / \mathrm{g})$} \\
\hline $0-7 d$ & 1.53 & 1.50 & 1.38 & 1.44 & 1.42 & 0.022 & 0.129 & 0.251 & 0.515 & 0.831 \\
\hline $7-14 d$ & $1.79^{\mathrm{x}}$ & $1.75^{\mathrm{x}}$ & $1.65^{x y}$ & $1.68^{x y}$ & $1.60^{y}$ & 0.022 & 0.007 & 0.027 & 0.424 & 0.252 \\
\hline $14-21 d$ & 1.90 & 1.95 & 1.85 & 1.77 & 1.83 & 0.028 & 0.425 & 0.185 & 0.800 & 0.485 \\
\hline $21-28 d$ & 3.13 & 3.14 & 2.58 & 2.86 & 2.52 & 0.091 & 0.042 & 0.036 & 0.842 & 0.249 \\
\hline $0-28 d$ & 2.15 & 2.09 & 1.97 & 2.01 & 2.12 & 0.042 & 0.834 & 0.821 & 0.277 & 0.419 \\
\hline \multicolumn{11}{|c|}{ Content viscosity (cpo $)^{\mathrm{b}}$} \\
\hline $\mathrm{D}+\mathrm{J}$ & $17.63^{x}$ & $12.03^{x y}$ & $9.30^{x y}$ & $13.91^{x y}$ & $6.06^{y}$ & 1.22 & 0.005 & 0.131 & 0.370 & 0.025 \\
\hline Ileum & $28.88^{x}$ & $28.98^{x}$ & $30.90^{x}$ & $29.37^{x}$ & $16.67^{y}$ & 1.65 & 0.019 & 0.018 & 0.013 & 0.013 \\
\hline
\end{tabular}

Means in the same line with different letter superscripts $(\mathrm{x}, \mathrm{y}, \mathrm{z})$ are significantly different $(\mathrm{P}<0.05)$.

a Treatments consisted of a rye-based diet not supplemented (R0) or supplemented with enzyme for the first 7 days (R1-7), the first 14 days (R1-14), the first 21 days (R1-21) or the entire 28 days (R1-28). $N=32$.

b Measurements were taken at 28 days of age. $N=8$.

\section{Results}

Weekly BW of birds fed a fully supplemented diet was not significantly different (P>0.05) from the BW of birds fed a supplemented diet on the first 14 (R1-14) or the first 21 (R1-21) days of age (Table 2). In addition, unsupplemented birds ( R0) had a lower $(\mathrm{P}<0.05)$ BW than birds fed the supplemented diet during the first 21 days of the trial (R1-21) or throughout the experiment (R1-28) and a similar BW to birds supplemented with the exogenous xylanase for the first 7 (R1-7) or 14 (R1-14) days of the trial, but only during the last week of the experiment (Table 2). There were no significant differences $(\mathrm{P}>0.05)$ in feed intake in birds of treatments R1-21 and R1-28 throughout the experiment. Feed conversion ratio when compared between unsupplemented (R0) and fully-supplemented (R1-28) birds was only different during the second week of age (Table 2). The mortality rate of the experiment was $5 \%$ and was not related to treatments. The weight and length, relative to BW, of the various GI compartments were unaffected $(P>0.05)$ by treatment (data not shown). In contrast, a significant reduction in viscosity of duodenum and jejunum and ileum digesta samples of birds supplemented with the exogenous xylanase when compared with the non supplemented animals was exclusively observed in animals supplemented during the entire period of the experiment (Table 2).

\section{Discussion}

Since previous experiments suggested that response to enzyme supplementation to diets containing barley or rye occurs mainly in the early stages of the broiler's life (Newman and Newman, 1988; Rotter et al., 1989; Nahas and Lefrançois, 2001; Mourão and Pinheiro, 2009), the present study investigated the restriction of enzyme supplementation to a rye-based diet in the initial stages of growth. Body weight of broilers fed fully supplemented rye-based diets was higher than unsupplemented birds, which is in accordance with previously reported results (Marquardt et al., 1996; Silva and Smithard, 2002; Lazaro et al., 2003). The data of the present experiment revealed that supplementation of birds fed a rye-based diet with exogenous enzymes may be restricted to the first 21 days of age since it was found that final BW, FCR and feed intake was not significantly different between broilers receiving exogenous enzymes for the first 21 days and those receiving enzyme for the entire 28 days of the experiment. This indicates that in diets containing a significant proportion of soluble NSP, enzymes have a direct effect on performance by supplementing the digestive capacity of the younger bird, as suggested by Bedford (2000). In addition, when animals are fed rye-based diets, the period of enzyme supplementation may, in general, be circumscribed to the initial stages of growth (until day 21). However, different rye varieties may yield different digesta viscosities which could influence performance for a longer period. Thus, it remains to be investigated if 21 days of supplementation with exogenous enzymes is appropriate for rye varieties presenting different levels of arabinoxylans.

Diets with high levels of soluble NSP may induce considerable enlargements of some portions of the GI tract (Brenes et al., 1993). The addition of exogenous enzymes decreases digesta viscosity and therefore improves feed passage rate and 
nutrient absorption, which may lead to a decrease in the relative weight of the digestive tract and a possible improvement in carcass yield. In the current rye-based diet study, however, the relative weights and lengths of the GI compartments were not significantly different between treatments. In previous rye-based diets studies, data suggested that enzyme supplementation only affects crop weight and jejunum length (Boros et al., 2002; Lazaro et al., 2004).

In the present experiment, and according to several other authors, viscosity was found to be lower in the digesta of birds consuming enzyme supplemented diets throughout the entire experimental period (Smits and Annison, 1996; Lazaro et al., 2003, 2004). This was apparent in both the contents of the foregut and hindgut of birds consuming rye-based diets. Since digesta viscosity was measured only on the last day of the experiment, it was expected that birds supplemented throughout the entire life had lower viscosity since at the time of slaughter only these animals were being fed enzyme supplemented diets. The reduction of viscosity of the digestive content observed with enzyme supplementation may have allowed a faster transit of digesta and facilitated contact between nutrients and digestive enzymes to improve nutrient digestibility (Langhout et al., 1997; Lazaro et al., 2003). Rye is perhaps the most problematic cereal in terms of intestinal viscosity. Thus, enzyme supplementation may have lead to a decrease in the retention time of digesta in the gut, with subsequent improved growth.

In conclusion, the current study indicates that enzyme supplementation to a rye-based diet is particularly effective in the early periods of animal growth. Enzyme supplementation during the entire length of the study was not required and was replaced by a restricted supplementation in the first 21 days. These observations may be of significant value to commercial feed manufacturers and poultry producers as they may represent important savings in the industry.

\section{Acknowledgements}

This work was supported by Fundação para a Ciência e a Tecnologia (PTDC/CVT/69329/2006). T. Ribeiro and P.I.P. Ponte were supported by Fundação para a Ciência e Tecnologia through grants SFRH/BD/32321/2006 and SFRH/BD/17969/2004, respectively.

\section{References}

Antoniou, T., Marquardt, R.R., 1981. Influence of rye pentosans on the growth of chicks. Poult. Sci. 60, 1898-1904.

Bedford, M.R., 1993. Mode of action of feed enzymes. J. Appl. Poult. Res. 2, 85-92.

Bedford, M.R., 2000. Exogenous enzymes in monogastric nutrition - their current value and future benefits. Anim. Feed Sci. Technol. $86,1-13$.

Boros, D., Marquardt, R.R., Guenter, W., Brufau, J., 2002. Chick adaptation to diets based on milling fractions of rye varying in arabinoxylans content. Anim. Feed Sci. Technol. 101, 135-149.

Brenes, A.M.S., Smith, M., Guenter, W., Marquardt, R.R., 1993. Effect of enzyme supplementation on the performance and digestive tract size of broiler chickens fed wheat- and barley-based diets. Poult. Sci. 72, 1731-1739.

Choct, M., Annison, G., 1990. Antinutritive activity of wheat pentosans in broiler diets. Br. Poult. Sci. 31, 811-821.

Dusel, G., Kluge, H., Jeroch, H., 1998. Xylanase supplementation of wheat-based rations for broilers: influence of wheat characteristics. J. Appl. Poult. Res. 7, 119-131.

Feedstuffs, 2009. Ingredient analysis table: 2009 edition. In: Reference Issue and Buyers Guide.

Józefiak, D., Rutkowski, A., Jensen, B.B., Engberg, R.M., 2007. Effects of dietary inclusion of triticale, rye and wheat and xylanase supplementation on growth performance of broiler chickens and fermentation in the gastrointestinal tract. Anim. Feed Sci. Technol. 132, 79-93.

Knudsen, K.E.B., 1997. Carbohydrate and lignin contents of plant materials used in animal feeding. Anim. Feed Sci. Technol. 67, 319-338.

Langhout, D.J., Schutte, J.B., Geerse, C., Kies, A.E., De Jong, J., Verstegen, M.W.A., 1997. Effects on chick performance and nutrient digestibility of an endoxylanase added to a wheat- and rye-based diet in relation to fat source. Br. Poult. Sci. 38, 557-563.

Lazaro, R., Gracia, M., Aranibar, M.J., Mateos, G.G., 2003. Effect of enzyme addition to wheat-, barley- and rye-based diets on nutrient digestibility and performance of laying hens. Br. Poult. Sci. 44, 256-265.

Lazaro, R., Latorre, M.A., Medel, P., Gracia, M., Mateos, G.G., 2004. Feeding regimen and enzyme supplementation to rye-based diets for broilers. Poult. Sci. 83, $152-160$

Marquardt, R.R., Brenes, A., Zhang, Z.Q., Boros, D., 1996. Use of enzymes to improve nutrient availability in poultry feedstuffs. Anim. Feed Sci. Technol. 60, 321-330.

Mourão, J., Pinheiro, V., 2009. Effects of rye, wheat and xylanase supplementation on diet nutritive value and broiler chicken performance. R. Bras. Zootec. 38, 2417-2424.

Nahas, J., Lefrançois, M.R., 2001. Effects of feeding locally grown whole barley with or without enzyme addition and whole wheat on broiler performance and carcass traits. Poult. Sci. 80, 195-202.

National Research Council, 1994. Nutrient Requirements of Poultry, 9th rev. ed. National Academy of Sciences, Washington, DC.

Newman, R.K., Newman, C.W., 1988. Nutritive-value of a new hull-less barley cultivar in broiler chick diets. Poult. Sci. 67, 1573-1579.

Rotter, B.A., Neskar, M., Guenter, W., Marquardt, R.R., 1989. Effect of enzyme supplementation on the nutritive value of hulless barley in chicken diets. Anim. Feed Sci. Technol. 24, 233-245.

SAS, 2001. SAS User' Guide: Statistics. Version 8. SAS Institute Inc., Cary, NC.

Silva, S.S.P., Smithard, R.R., 2002. Effect of enzyme supplementation of a rye-based diet on xylanase activity in the small intestine of broilers, on intestinal crypt cell proliferation and on nutrient digestibility and growth performance of the birds. Br. Poult. Sci. 43, 274-282.

Smits, C.H., Annison, G., 1996. Non-starch plant polysaccharides in broiler nutrition towards a physiological valid approach to their determination. Worlds Poult. Sci. J. 52, 203-221. 